\title{
Global Isotopic Hydrograph Separation Research History and Trends: A Text Mining and Bibliometric Analysis Study
}

\author{
Yunlong Yu ${ }^{1,2,3}$, Zhao Jin ${ }^{2,4, *(1)}$ and Junping Qiu ${ }^{1,3, *}$ \\ 1 Academy of Data Science and Informetrics, Hangzhou Dianzi University, Hangzhou 310018, China; \\ yuyl@hdu.edu.cn \\ 2 State Key Laboratory of Loess and Quaternary Geology, Institute of Earth Environment, \\ Chinese Academy of Sciences, $X^{\prime}$ an 710061, China \\ 3 School of Management, Hangzhou Dianzi University, Hangzhou 310018, China \\ 4 CAS Center for Excellence in Quaternary Science and Global Change, Chinese Academy of Sciences, \\ Xi'an 710061, China \\ * Correspondence: jinzhao@ieecas.cn (Z.J.); jpqiu@whu.edu.cn (J.Q.); Tel.: +86-134-6866-9232 (Z.J.); \\ +86-199-6747-3138 (J.Q.)
}

Citation: Yu, Y.; Jin, Z.; Qiu, J. Global Isotopic Hydrograph Separation Research History and Trends: A Text Mining and Bibliometric Analysis Study. Water 2021, 13, 2529. https:// doi.org/10.3390/w13182529

Academic Editor: Maurizio Barbier

Received: 11 August 2021

Accepted: 13 September 2021

Published: 15 September 2021

Publisher's Note: MDPI stays neutral with regard to jurisdictional claims in published maps and institutional affiliations.

Copyright: (c) 2021 by the authors. Licensee MDPI, Basel, Switzerland. This article is an open access article distributed under the terms and conditions of the Creative Commons Attribution (CC BY) license (https:// creativecommons.org/licenses/by/ $4.0 /)$.

\begin{abstract}
Scientific research into isotope hydrograph separation (IHS) has rapidly increased in recent years. However, there is a lack of systematic and quantitative research to explore how this field has evolved over time. In this study, the methods of text mining and bibliometric analysis were combined to address this shortcoming. The results showed that there were clear periodical characteristics in IHS studies between 1986 and 2019. High-frequency words, e.g., catchment, stable isotope, runoff, groundwater, precipitation, runoff generation, and soil, were the basic topics in IHS studies. Forest and glacier/snow were the main landscapes in this research field. 'Variation', 'spatial', and 'uncertainty' are hot issues for future research. Today, studies involving the geographical source, flow path, and transit/residence time of streamflow components have enhanced our understanding of the hydrological processes by using hydrometeorological measurements, water chemistry, and stable isotope approaches. In the future, new methods, such as path analysis and ensemble hydrograph separation, should be verified and used in more regions, especially in remote and mountainous areas. Additionally, the understanding of the role of surface water in streamflow components remains limited and should be deeply studied in the future.
\end{abstract}

Keywords: isotope hydrology; text mining; bibliometric indicator; web of science

\section{Introduction}

In 1969, Hubert et al. [1] published their pioneering paper on hydrograph separation using stable isotope tracers. Since then, isotope hydrograph separation (IHS) has gradually become the principal method for determining the relative contributions of different sources of runoff or streamflow (i.e., event or pre-event water) [2-5]. Buttle [6] summarized the hydrological processes, including groundwater ridging, lateral throughflow, preferential flow, saturation overland flow, kinematic waves, and output from surface storage, which significantly improved the knowledge of the mechanisms of runoff generation. In 2013, Klaus and McDonnell [7] published a qualitative and comprehensive review of IHS and concluded that, despite certain limitations, water stable isotopes were still the most effective technology for understanding runoff generation processes and mechanisms. Moreover, several IHS reviews have focused on streamflow generation and associated processes and methods in special environmental settings, which has accelerated the accumulation of IHS studies [8,9]. Since 2013, there has been a rapid increase in scientific output in the field, which provides an unprecedented opportunity to explore the dynamics of IHS research based on data from a large body of published scientific work. However, to our knowledge, there has not been a quantitative assessment of the publication data in this field, and 
there are limited documents on text mining and relevant data science methods applied in hydrology research. Utilizing a quantitative and systemic method, we can analyze the characteristics and performances of documents to gain both macro- and micro-insights into the history and development of the field.

Similar to all scientific fields, the study of IHS has changed over time. Interests in certain themes have emerged and disappeared, and the breadth and depth of research content have expanded [10]. The most significant advances were made around the five well-known assumptions implicit in IHS models [9]. The five underlying assumptions are listed as follows: (1) significant isotopic differences occurred between the pre-event (old) and event (new) water; (2) the new water retains a constant isotopic signature in space and time, or any variations can be accounted for; (3) the isotopic signature of the old water is constant in space and time, or any variations can be accounted for; (4) contributions of water from the vadose zone must be negligible, or the isotopic content of soil water must be similar to that of groundwater; and (5) the contributions from surface storage to streamflow are negligible. Many IHS studies have concentrated on the validity and effects of these assumptions in recent decades [2,11-17]. Tracing IHS literature by quantitative approaches is interesting and vital for enhancing the understanding of runoff generation and relevant hydrological processes.

Text mining is the process of automatically extracting high-quality information from unstructured or structured texts with diverse formats and types using linguistic and statistical techniques [18,19]. Thematic analysis is an important subject of textual data mining. Studies have found that temporal changes in themes, usually represented by keywords for a given research domain, can help to uncover the evolution of a topic and its trend [20-22]. For example, Yao et al. [23] analyzed the frequency changes in author keywords related to nitrogen in eutrophic lakes or reservoirs at five-year intervals and successfully determined the current and future trends in nitrogen field research. Chen et al. [24] analyzed research trends in management science and engineering in China based on co-keyword analysis and concluded that the foci were game theory, supply chain management, complex networks, data mining, optimization, risk management, and data envelopment analysis. In addition, theme variations based on keyword analysis can also help new researchers to situate themselves and their topics within the field and within changing research interests. Similarly, a systemic analysis of the thematic changes in IHS research is indispensable to understanding how this field evolved over time and predicting future research trends.

Bibliometric analysis is a popular, powerful, and systematic way to analyze the performance of scientific production using mathematical and statistical methods $[25,26]$. The results of bibliometric analyses can provide objective views of scientific productions in a given research field and provide effective support for the subjective perceptions of researchers. Many research fields have applied this methodology to assess and predict scientific productivity, development, and future trends [27,28]. Padilla et al. [29], for example, conducted a bibliometric analysis of global nitrate leaching publications and found an overriding interest in recent decades on the theme of soil nitrogen loss in agroecosystems. Moreover, many different bibliometric indicators can be used to evaluate the literature characteristics as well as thematic influences, such as the number of documents, number of citations, and rank [30]. A quantitative analysis of bibliometric indicators can reveal the most cited papers, hot issues, and other valuable information in a given research field, which can help scientists to quickly develop an understanding of the research situation in their field [31,32]. Therefore, an analysis of the performance of themes with bibliometric indicators is of vital importance in understanding the global state of IHS.

Based on the techniques of text mining and bibliometric analysis, this study analyzed the evolving history and future trends of IHS research from a global perspective by using the Web of Science (WoS) database. The aims of this study were to (1) quantitatively summarize the characteristics of yearly publication and explore the development nature of IHS; (2) mine and assess IHS themes in different subperiods and reveal how these themes 
enhance our understanding of hydrological processes related to IHS, and (3) discuss the upcoming research trends and provide a certain guide for future IHS research.

\section{Materials and Methods}

\subsection{Data Sources}

The WoS is a powerful literature database that can provide good access to bibliometric indicators of the published items and allow us to explore the literature in scientific fields. Moreover, the WoS database includes complete citation data of specific domains, covering more than 20,000 journals, conference proceedings, and books. Thus, our bibliometric analysis was conducted based on the literature from the WoS database. We started by searching for the topic keywords (including 'Title', 'Abstract', 'Author Keywords', and 'Keywords Plus') 'hydrograph separation"' and 'isotope' or 'isotopic' from the core WoS collection. We limited the research period to 1969 to 2019 and limited the document types to articles, proceedings, and reviews. Keywords and abstracts from before 1990 are not available on the WoS, so the number of documents collected before 1990 is limited [33,34]. In total, 392 publications from 1986 to 2019 met the selection criteria, and the full records and cited references of each were downloaded in plain text format for further analysis. Most publications (389) are written in English, two are written in French, and one is written in Spanish.

\subsection{Analytical Methods}

We extracted various performance indicators from 392 downloaded IHS recodes to conduct a bibliometric analysis that included frequency calculation, co-word analysis, and science mapping. Science mapping is a spatial representation of how disciplines, domains, specialities, and individual research units relate to one another [35]. Frequency calculations are widely used in bibliometric analyses to investigate the influence of research units, such as publications, authors, and countries/regions, by counting the number of documents and total citations (TC) or global citation scores (GCS), local citation scores (LCS), and themes based on counting words of interest [28]. LCS is the number of citations of one document by other documents in the collected dataset, while TC or GCS is the number of citations of one document by the documents in the WoS core collection [23]. More information on the relevant bibliometric indicators in this study is shown in Table 1. In this study, the primary bibliometric index of assessing the influence of research activities was LCS, followed by the number of publications, then others.

Author keywords (AKs), which are one part of most articles that name 'Keywords' added by authors, play a prominent role within the different sections of a document. Keywords Plus (PKs), which can be considered an extension of AKs that added by the WoS, could increase retrieval effectiveness. AKs and PKs generally represent the main ideas, content, and other valuable information contained in a paper [36]. Therefore, many studies have applied AKs or PKs or have coupled AKs with PKs in different time intervals to investigate themes, hotspots, or trends during specific research subperiods $[23,29,37]$. We chose to jointly use the document AKs and PKs because some documents lacked AKs. A normalization process was conducted before beginning the theme evolution analysis. First, spelling errors were corrected. Then, the plural forms of keywords were changed to their singular forms. Finally, acronyms were added to the respective keywords. We used an approach that included co-word analysis, strategic and Sankey diagrams, and performance analysis of themes developed by Cobo et al. [38] to detect, quantify, and visualize the evolution and trends in IHS research. Several studies have employed this method to explore the thematic developments and trends in analyzed research domains [39]. 
Table 1. Bibliometric indicators and their formulas.

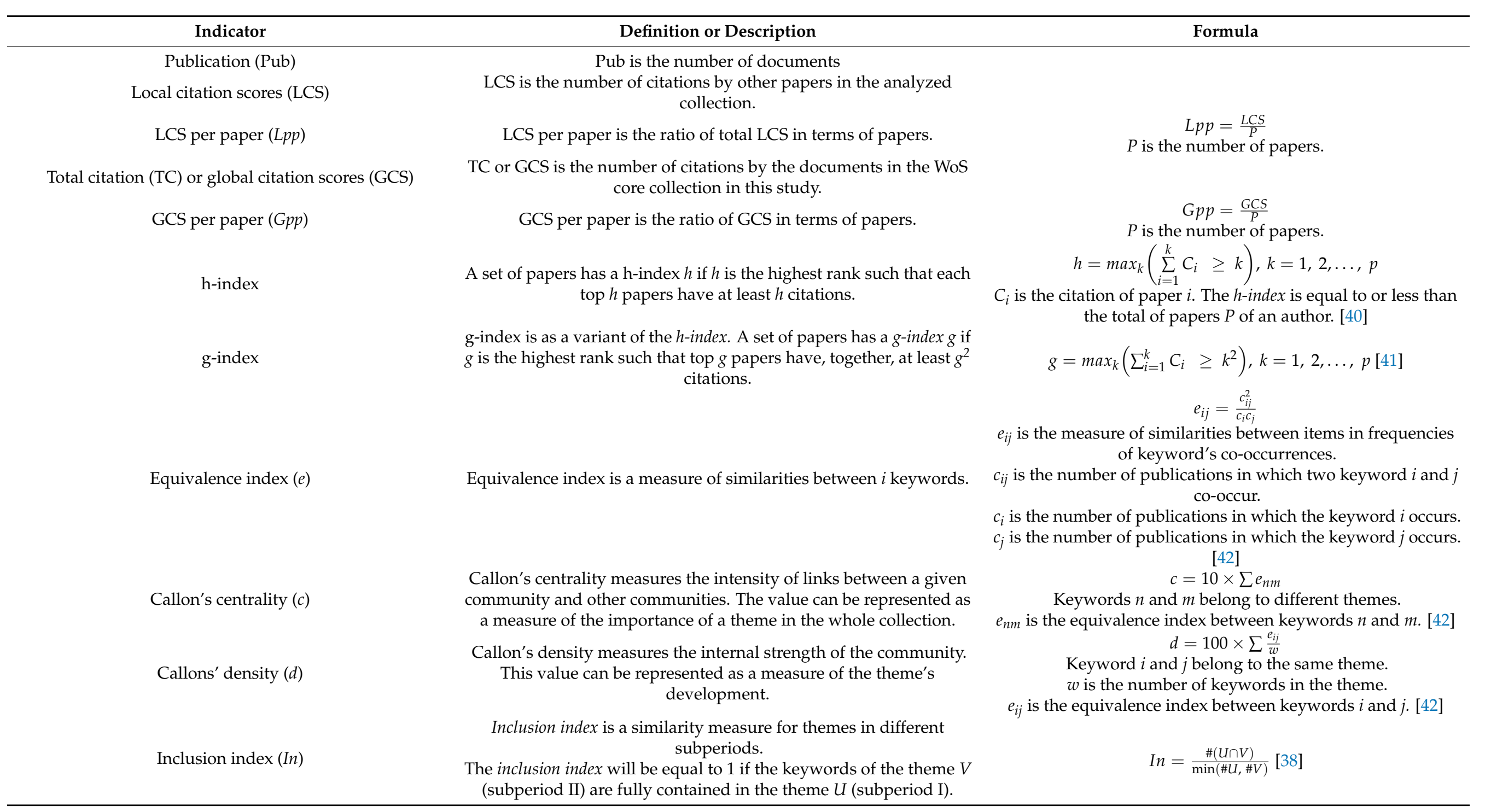


The main concepts of a specific field could be discovered using co-word analysis. Moreover, co-word analysis is a powerful method to discover and describe the interactions between different research topics [38]. The methodological foundation of co-word analysis is the idea that the co-occurrence of keywords describes the contents of the documents in a file [42]. An equivalence index and clustering were applied to measure the keyword co-occurrence matrix [42,43] (Table 1). In this study, co-word analysis, including the cooccurrence and clustering of keywords, was used to detect themes through each subperiod. It was possible that there was more than one theme in one paper.

Then, two indicators, Callon's centrality and Callon's density, can be used to measure the performance of the themes in each subperiod [42] (Table 1). Callon's centrality is an indicator of the importance of a theme across a full set of publications, while Callon's density is an indicator of the theme's development. Then, a strategic diagram was applied to show the themes with different Callon's centrality ( $x$-axis) and density ( $y$-axis) [37] (Figure 1). The themes with high density and high centrality were named motor themes (important and developed topics that show strong links with other themes in other quadrants), which were located in quadrant I; those with low density and high centrality were developed and isolated themes, which were located in quadrant II; those with low density and low centrality were emerging or declining themes, which were located in quadrant III; and those with low density and high centrality were basic and transversal themes (focusing on general issues that were transversal to the different research areas of a domain), which were located in quadrant IV. Then, a strategic diagram was constructed to assess the role of each theme in each subperiod qualitatively. Severe bibliometric indicators were used to quantify the impact of themes in different subperiods. Finally, a Sankey diagram was applied to present how different themes were connected and developed over previous decades. Thematic analysis and visualization, supplemented by the interpretation of important documents, help us clearly capture the details of IHS development and enhance our understanding of hydrological processes in streamflow generation.

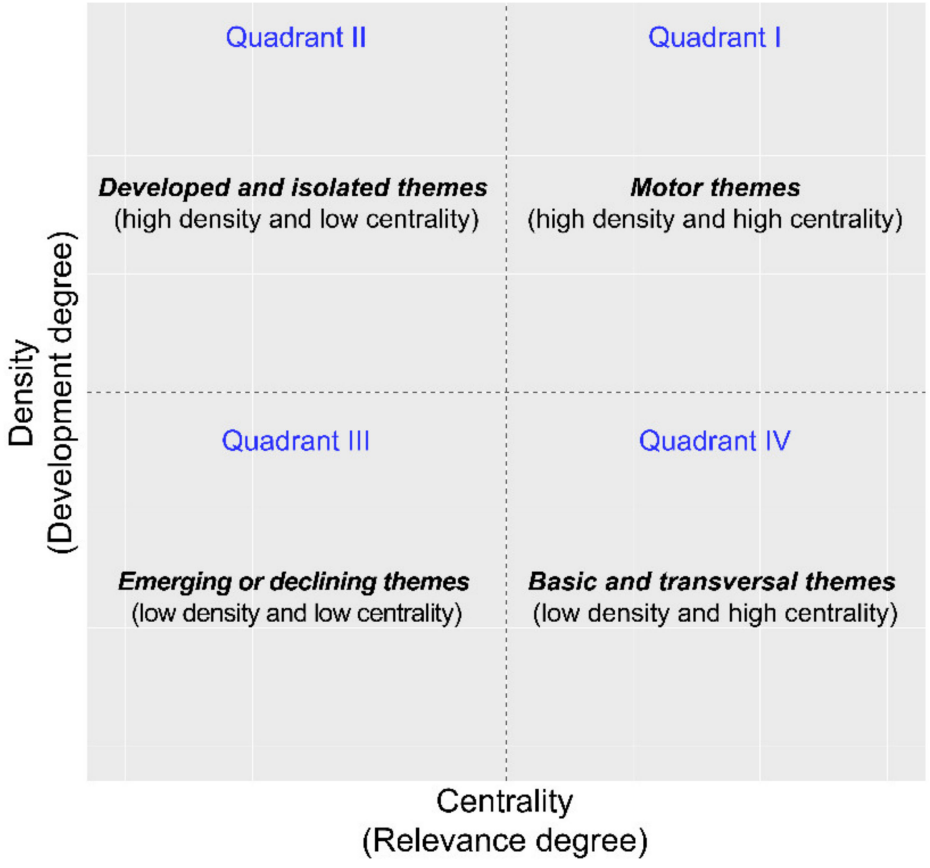

Figure 1. Strategic diagram modified from Cobo et al. [38].

All analyses were performed using R 4.0.2 software ( $R$ Core Team, 2020). The bibliometric and thematic analysis was mainly carried out using an open-source $\mathrm{R}$ package named the bibliometrix package built by Aria and Cuccurullo [44]. 


\section{Results}

\subsection{Publication and Keyword Performance}

The primary information and statistics regarding the analyzed IHS collection are reported in Table 2. The 392 IHS documents published in 87 sources were written by 1138 authors from 453 institutions in 53 countries. The numbers of TC and average citations per document were 12,413 and 31.67, respectively. The annual growth rate was, on average, $11.3 \%$. Figure 2 shows the yearly output of IHS documents published from 1986 to 2019 . The output presented obvious periodical characteristics in terms of the mean value of yearly publications. The whole period could be divided into three subperiod based on the significant changes in average publication output. Before 2000 (subperiod I), the literature output grew slowly, with only 50 documents in 13 years and an average annual output of only 3.6. From 2000 to 2014 (subperiod II), the annual volume of documents increased, with an average production of 11.7 documents per year. The most influential literatures were published in subperiods I and II (Table 3). During 2015 and 2019 (subperiod III), there was a significant upward trend in the number of cumulative publications, increasing from 225 in 2014 to 392 in 2019. The mean output of 33.4 in this subperiod was much higher than that in the other two subperiods. No important literature was published in subperiod III, but this may be due to delayed citing. The number of cumulative documents grew from 1986, following a quadratic function in the form of $y=157,000-158 x+0.04 x^{2}$ (adjusted $R^{2}=0.988, p<0.001$ ), indicating that there is a generally increasing trend in IHS publications.

Table 2. Principal information about the 1986-2019 IHS collection.

\begin{tabular}{cc}
\hline Description & Results \\
\hline Total documents & 392 \\
Timespan & $1986: 2019$ \\
Annual growth rate & $11.28 \%$ \\
Total citations (TC) & 12,413 \\
Average citations per document & 31.67 \\
Sources & 87 \\
Authors & 1138 \\
Institutions & 453 \\
Countries & 53 \\
\hline
\end{tabular}

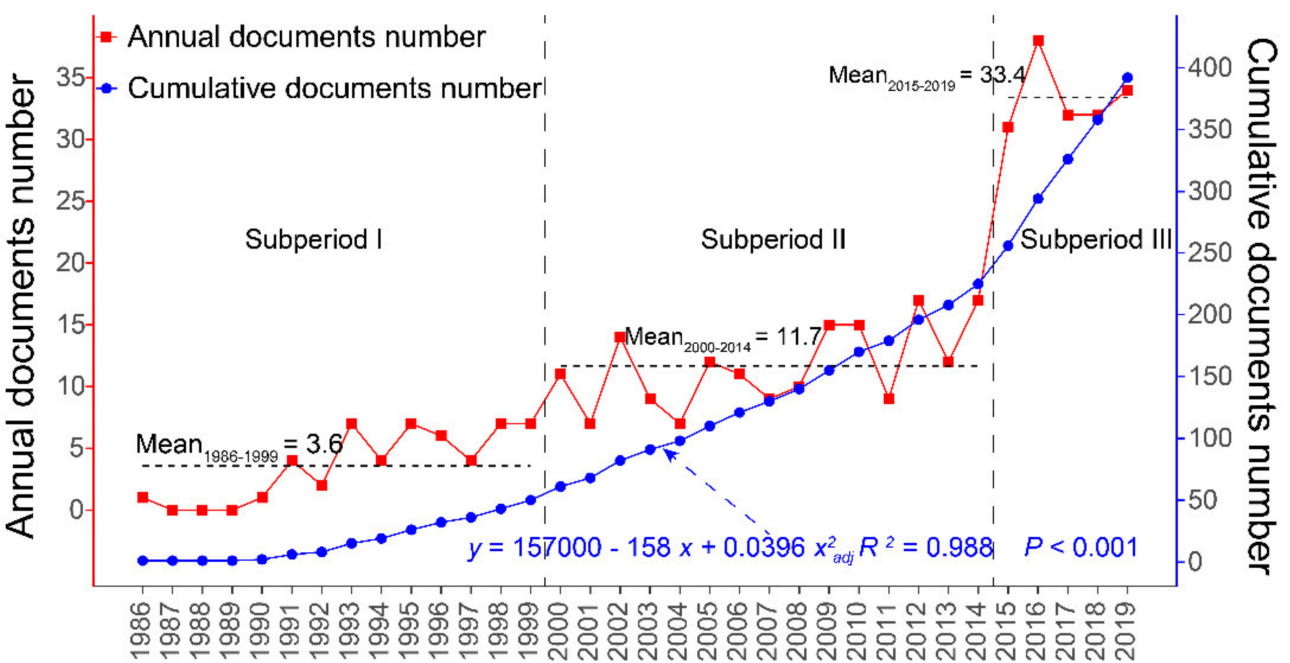

Figure 2. The publication output of IHS between 1986 and 2019. The transverse dashed lines present the mean values of the number of documents per year in each subperiod. 
Table 3. Twenty most influential papers based on LCS.

\begin{tabular}{|c|c|c|c|c|c|}
\hline Paper & Digital Object Identifier (DOI) & LCS & GCS & LCS Per Year & GCS Per Year \\
\hline $\begin{array}{l}\text { Buttle JM, 1994, Prog Phys Geog } \\
\text { (IF: 3.580) [6] }\end{array}$ & $10.1177 / 030913339401800102$ & 118 & 297 & 4.4 & 11.0 \\
\hline $\begin{array}{l}\text { Klaus J, 2013, J Hydrol (IF: } \\
\text { 5.722) [7] }\end{array}$ & 10.1016/j.jhydrol.2013.09.006 & 92 & 221 & 11.5 & 27.6 \\
\hline $\begin{array}{c}\text { Hooper RP, 1986, Water Resour } \\
\text { Res (IF: 5.240) [45] }\end{array}$ & 10.1029/WR022i010p01444 & 88 & 252 & 2.5 & 7.2 \\
\hline Wels C, 1991, J Hydrol [46] & 10.1016/0022-1694(91)90181-G & 60 & 139 & 2.0 & 4.6 \\
\hline $\begin{array}{c}\text { Laudon H, 2002, Water Resour } \\
\text { Res [47] }\end{array}$ & 10.1029/2002WR001510 & 51 & 80 & 2.7 & 4.2 \\
\hline Brown VA, 1999, J Hydrol [3] & 10.1016/S0022-1694(98)00247-9 & 46 & 187 & 2.1 & 8.5 \\
\hline $\begin{array}{c}\text { Taylor S, 2001, Water Resour } \\
\text { Res [13] }\end{array}$ & 10.1029/2000WR900341 & 44 & 129 & 2.2 & 6.5 \\
\hline $\begin{array}{c}\text { Ogunkoya OO, 1993, J Hydrol } \\
{[48]}\end{array}$ & 10.1016/0022-1694(93)90005-T & 43 & 93 & 1.5 & 3.3 \\
\hline Kong YL, 2012, J Hydrol [49] & 10.1016/j.jhydrol.2012.02.029 & 41 & 78 & 4.6 & 8.7 \\
\hline $\begin{array}{c}\text { Hinton MJ, 1994, Water Resour } \\
\text { Res [50] }\end{array}$ & 10.1029/93WR03246 & 39 & 110 & 1.4 & 4.1 \\
\hline Laudon H, 1997, J Hydrol [51] & 10.1016/S0022-1694(97)00030-9 & 38 & 85 & 1.6 & 3.5 \\
\hline Ladouche B, 2001, J Hydrol [52] & 10.1016/S0022-1694(00)00391-7 & 38 & 136 & 1.9 & 6.8 \\
\hline $\begin{array}{l}\text { Taylor S, 2002, Hydrol Process } \\
\text { (IF: 3.565) [53] }\end{array}$ & 10.1002/hyp.1232 & 38 & 69 & 2.0 & 3.6 \\
\hline $\begin{array}{c}\text { Shanley JB, 2002, Hydrol } \\
\text { Process [54] }\end{array}$ & 10.1002/hyp.312 & 35 & 94 & 1.8 & 4.9 \\
\hline $\begin{array}{c}\text { Lyon SW, 2009, Hydrol Process } \\
\text { [55] }\end{array}$ & 10.1002/hyp.7326 & 35 & 56 & 2.9 & 4.7 \\
\hline Liu YH, 2008, J Hydrol [56] & 10.1016/j.jhydrol.2008.02.017 & 33 & 62 & 2.5 & 4.8 \\
\hline $\begin{array}{c}\text { Mcdonnell JJ, 1991, Water } \\
\text { Resour Res [4] }\end{array}$ & 10.1029/91WR02025 & 31 & 126 & 1.0 & 4.2 \\
\hline $\begin{array}{l}\text { Bazemore DE, 1994, J Hydrol } \\
\text { [57] }\end{array}$ & $10.1016 / 0022-1694(94) 90004-3$ & 31 & 137 & 1.1 & 5.1 \\
\hline $\begin{array}{c}\text { Unnikrishna PV, 2002, J Hydrol } \\
\text { [58] }\end{array}$ & 10.1016/S0022-1694(01)00596-0 & 28 & 66 & 1.5 & 3.5 \\
\hline $\begin{array}{c}\text { Weiler M, 2003, Water Resour } \\
\text { Res [59] }\end{array}$ & 10.1029/2003WR002331 & 28 & 146 & 1.6 & 8.1 \\
\hline
\end{tabular}

IF: Impact Factor of 2020 Journal Citation Reports.

Two papers published before 1991 were excluded from the textual analysis because there were no keywords in these documents. Table 4 presents the number of publications and keywords per period. The number of keywords used per year was 17.6, 42.1, and 125.8 in subperiods I, II, and III, respectively, showing a noticeable expansion in research topics over time. There were 158 keywords in all of subperiod I, including 'runoff' (19), 'storm' (19), 'groundwater' (17), 'catchment' (16), and 'flow' (14), located in the center of the word cloud of subperiod I (Figure 3a). There was a significant increase to 632 keywords in subperiod II. 'Catchment' (99) rose in rank from the fourth to first position (in the center of the word cloud of subperiod II), and 'soil' rose from the thirteenth (6) to third position (51), which was close to the 'catchment' (Figure 3b). There were 629 keywords in subperiod III, including 'stable-isotope' (99), 'catchment' (90), 'groundwater' (61), 'runoff' (60), 'precipitation' (59), 'river' (55), and 'basin' (51) (in the center of the word cloud of subperiod III (Figure 3c)). Some keywords, such as 'variation' and 'spatial', merely appeared in subperiods II and III, and the sum frequency of the two terms increased from subperiod II to subperiod III.

\subsection{Thematic Distribution and Evolution}

To further explore the topics of IHS, the co-word matrix and clustering methods were applied to determine the themes in different subperiods. The themes of different subperiods using strategic diagrams are presented in Figure $4 \mathrm{a}-\mathrm{c}$. Moreover, their evolution paths from 
subperiod I to subperiod III are clearly shown using a Sankey diagram in Figure 4d. Table 5 shows the top 10-most frequent keywords of each theme. The bibliometric indicators in Table 6 were used to measure the influence of each theme in different subperiods.

Table 4. Principal information in each subperiod.

\begin{tabular}{cccccc}
\hline Subperiod & Publication & $\begin{array}{c}\text { Percentage of Total } \\
\text { Publications (\%) }\end{array}$ & Keywords & $\begin{array}{c}\text { Percentage of Total } \\
\text { Keywords (\%) }\end{array}$ & $\begin{array}{c}\text { Keywords Per } \\
\text { Year }\end{array}$ \\
\hline $1991-1999$ & 44 & 11.5 & 158 & 11.1 & 17.6 \\
$2000-2014$ & 173 & 45.1 & 632 & 44.5 & 42.1 \\
$2015-2019$ & 167 & 43.5 & 629 & 44.3 & 125.8 \\
\hline
\end{tabular}

(a) Subperiod I

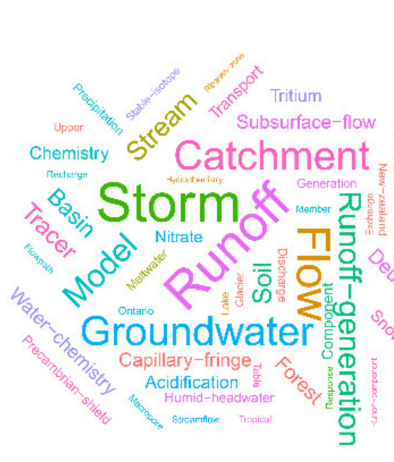

'(b) Subperiod II

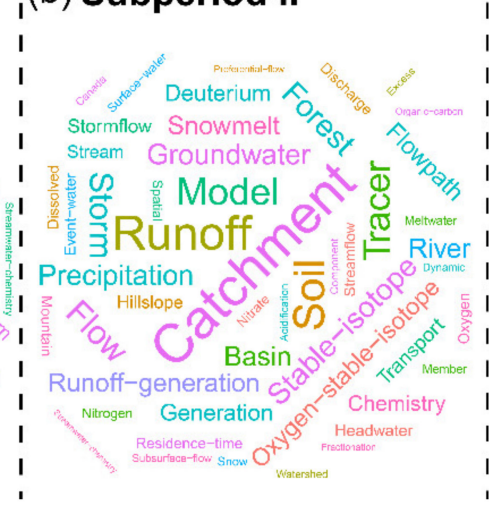

\section{;(c) Subperiod III}

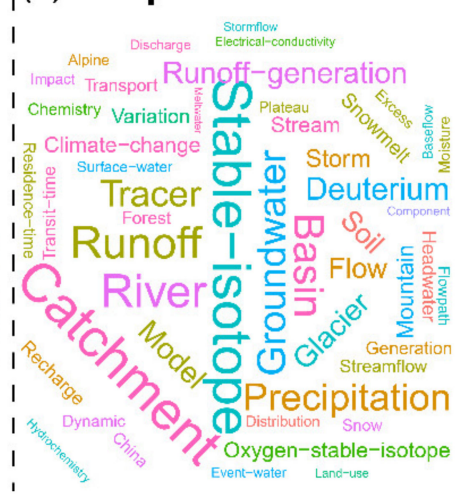

Figure 3. Word cloud of the most widely used IHS keywords in each subperiod. The size is proportional to the frequency of each keyword. The larger the word size is, the more important it is. For highlighting the important keywords, the keywords with high frequencies and large sizes locate in the center of the word could. (a) Subperiod I, (b) Subperiod II, (c) Subperiod III.
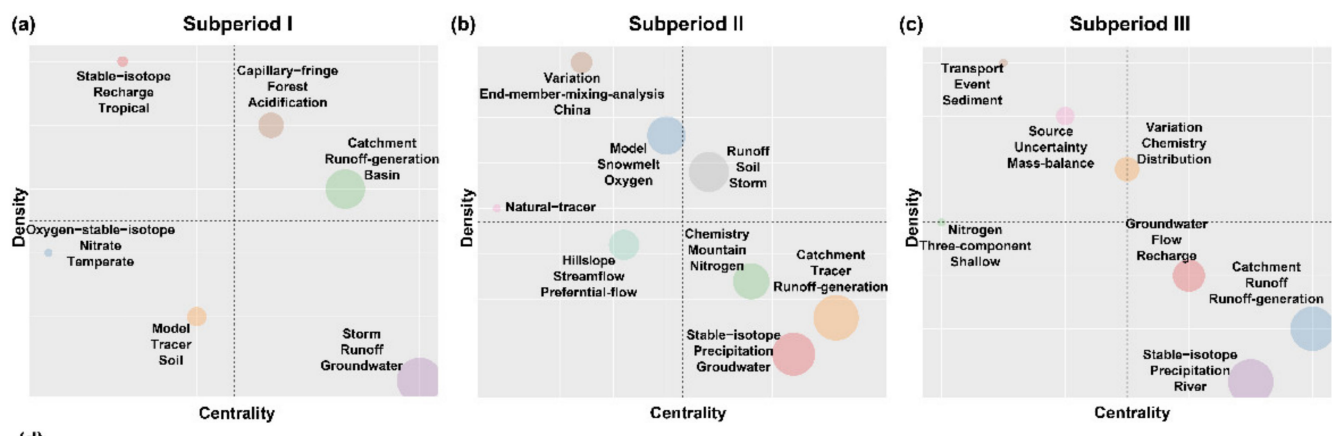

(d)

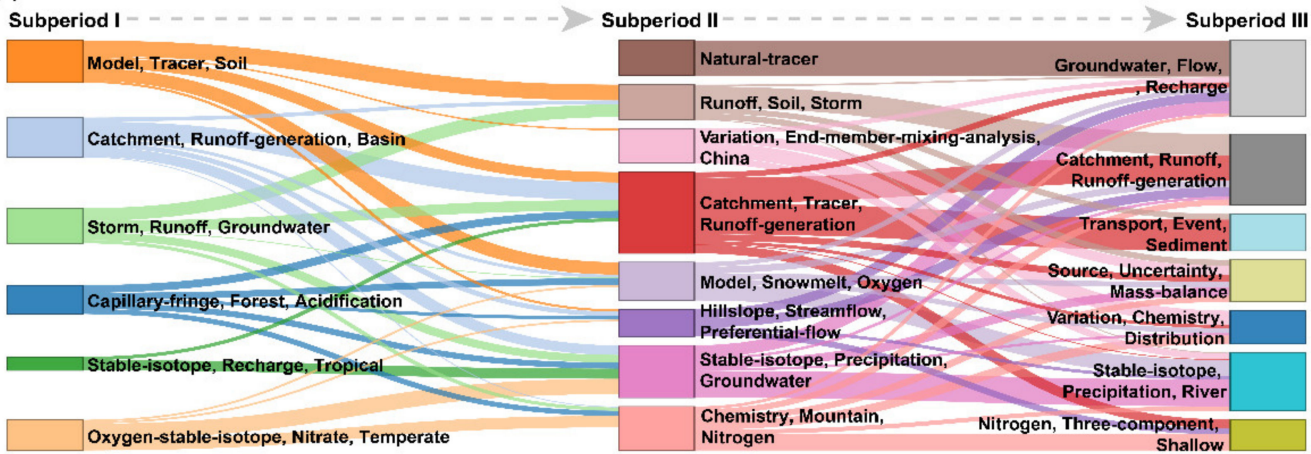

Figure 4. Thematic maps (strategic diagrams: a-c) and evolution (Sankey graph: d) of IHS. (a-c): The circle size is proportional to the total frequency of terms in each theme. Each theme is labeled with the corresponding three most frequent keywords; (d): Each theme is labeled with the corresponding three most frequent keywords. The thickness of the edges is proportional to the inclusion index. 
Table 5. Keywords of IHS themes in each subperiod.

\begin{tabular}{|c|c|c|c|}
\hline Theme & Frequency & Top 10 Most Frequent Keywords in Each Theme; the Number Following each Word Is the Frequency of the Word & Subperiod \\
\hline Storm; Runoff; Groundwater & 132 & $\begin{array}{c}\text { Storm 19; Runoff 19; Groundwater 17; Flow 14; Stream 8; Chemistry 5; Transport 4; Discharge 3; Environmental-Isotope 3; } \\
\text { Watershed } 2 \text {. }\end{array}$ & 1991-1999 \\
\hline Catchment; Runoff-Generation; Basin & 100 & $\begin{array}{c}\text { Catchment 16; Runoff-Generation 13; Basin 6; Deuterium 6; Subsurface-Flow 6; Water-Chemistry 6; Humid-Headwater 4; } \\
\text { Component 4; Tritium 4; New-Zealand } 3\end{array}$ & 1991-1999 \\
\hline Capillary-Fringe; Forest; Acidification & 52 & $\begin{array}{c}\text { Capillary-Fringe 6; Forest 5; Acidification 5; Snowmelt 4; Precambrian-Shield 4; Generation 3; Meltwater 3; Precipitation } \\
\text { 3; Streamflow 2; Ontario } 2\end{array}$ & 1991-1999 \\
\hline Model; Tracer; Soil & 39 & $\begin{array}{c}\text { Model 10; Tracer 6; Soil 6; Streamwater-Chemistry 3; Member 2; Macropore 2; Stormflow 1; Three-Component 1; } \\
\text { Two-Component 1; End-Member-Mixing-Analysis } 1\end{array}$ & 1991-1999 \\
\hline Stable-Isotope; Recharge; Tropical & 26 & Stable-Isotope 3; Recharge 2; Tropical 2; Exchange 2; Tectonic 1; Humid 1; Landform 1; Development 1; Etch 1; Africa 1 & 1991-1999 \\
\hline Oxygen-Stable-Isotope; Nitrate; Temperate & 23 & $\begin{array}{c}\text { Oxygen-Stable-Isotope 6; Nitrate 4; Temperate 1; Solute 1; Shallow 1; Ecosystem 1; Boreal 1; Leaching 1; Topmodel 1; } \\
\text { Mixing-Model } 1\end{array}$ & 1991-1999 \\
\hline Catchment; Tracer; Runoff-Generation & 597 & $\begin{array}{l}\text { Catchment 99; Tracer 46; Runoff-Generation 43; Flow 38; Forest 37; Flowpath 31; Generation 31; Transport 24; Stormflow } \\
\text { 23; Residence-Time } 19\end{array}$ & $2000-2014$ \\
\hline Stable-Isotope; Precipitation; Groundwater & 437 & $\begin{array}{c}\text { Stable-Isotope 48; Precipitation 44; Groundwater 44; Oxygen-Stable-Isotope 41; Basin 30; River 30; Deuterium 29; } \\
\text { Discharge 16; Surface-Water 13; Canada } 9\end{array}$ & $2000-2014$ \\
\hline Runoff; Soil; Storm & 298 & $\begin{array}{c}\text { Runoff 70; Soil 51; Storm 39; Event-Water 16; Dissolved 15; Member 11; Dynamic 10; Streamwater-Chemistry 10; } \\
\text { Organic-Carbon 10; Water-Chemistry } 8\end{array}$ & 2000-2014 \\
\hline Model; Snowmelt; Oxygen & 239 & $\begin{array}{c}\text { Model 50; Snowmelt 33; Oxygen 15; Meltwater 13; Snow 10; Fractionation 10; Component 10; Snowpack 9; Baseflow 8; } \\
\text { Spring } 8\end{array}$ & 2000-2014 \\
\hline Chemistry; Mountain; Nitrogen & 187 & $\begin{array}{c}\text { Chemistry 26; Mountain 15; Nitrogen 13; Nitrate 12; Acidification 11; Watershed 10; Alpine 8; USA 7; Sierra-Nevada 6; } \\
\text { Mixing-Model } 6\end{array}$ & 2000-2014 \\
\hline Hillslope; Streamflow; Preferential-Flow & 85 & $\begin{array}{l}\text { Hillslope 19; Streamflow 17; Preferential-Flow 11; Subsurface-Flow 11; Unsaturated 6; Subsurface 4; Shallow 4; Response } \\
\text { 4; Macropore 3; Runoff-Component } 3\end{array}$ & 2000-2014 \\
\hline Variation; End-Member-Mixing-Analysis; China & 28 & Variation 9; End-Member-Mixing-Analysis 6; China 4; Semi-Arid 3; Management 3; Sandy 3; & 2000-2014 \\
\hline Natural-Tracer & 5 & Natural-Tracer 5 & 2000-2014 \\
\hline Stable-Isotope; Precipitation; River & 760 & $\begin{array}{c}\text { Stable-Isotope 99; Precipitation 59; River 55; Basin 51; Deuterium 40; Oxygen-Stable-Isotope 33; Glacier 33; } \\
\text { Climate-Change 29; Mountain 27; Snowmelt } 23\end{array}$ & 2015-2019 \\
\hline Catchment; Runoff; Runoff-Generation & 696 & $\begin{array}{c}\text { Catchment 90; Runoff 60; Runoff-Generation 47; Tracer 41; Model 34; Soil 25; Storm 24; Headwater 22; Stream 22; } \\
\text { Residence-Time } 19\end{array}$ & 2015-2019 \\
\hline Groundwater; Flow; Recharge & 243 & $\begin{array}{c}\text { Groundwater 61; Flow 27; Recharge 21; Streamflow 19; Baseflow 13; Hydrochemistry 12; USA 8; Geochemistry 7; } \\
\text { Recession 7; Karst } 6\end{array}$ & 2015-2019 \\
\hline Variation; Chemistry; Distribution & 124 & $\begin{array}{c}\text { Variation 22; Chemistry 17; Distribution 15; Spatial 9; Connectivity 8; Snowpack 7; Canada 7; Control 6; Elevation 5; } \\
\text { Seasonal } 5\end{array}$ & 2015-2019 \\
\hline Source; Uncertainty; Mass-Balance & 73 & $\begin{array}{c}\text { Source 10; Uncertainty 10; Mass-Balance 8; Melt 7; Mixing-Model 7; End-Member-Mixing-Analysis 7; Balance 6; } \\
\text { Contribution 4; Colorado 4; Water-Chemistry } 4\end{array}$ & 2015-2019 \\
\hline Transport; Event; Sediment & 31 & Transport 18; Event 8; Sediment 5 & 2015-2019 \\
\hline Nitrogen; Three-Component; Shallow & 30 & Nitrogen 6; Three-Component 5; Shallow 5; Nitrate 5; Nutrient 3; Contaminant 3; Denitrification 3 & 2015-2019 \\
\hline
\end{tabular}


Table 6. Performance measures for the themes of each subperiod.

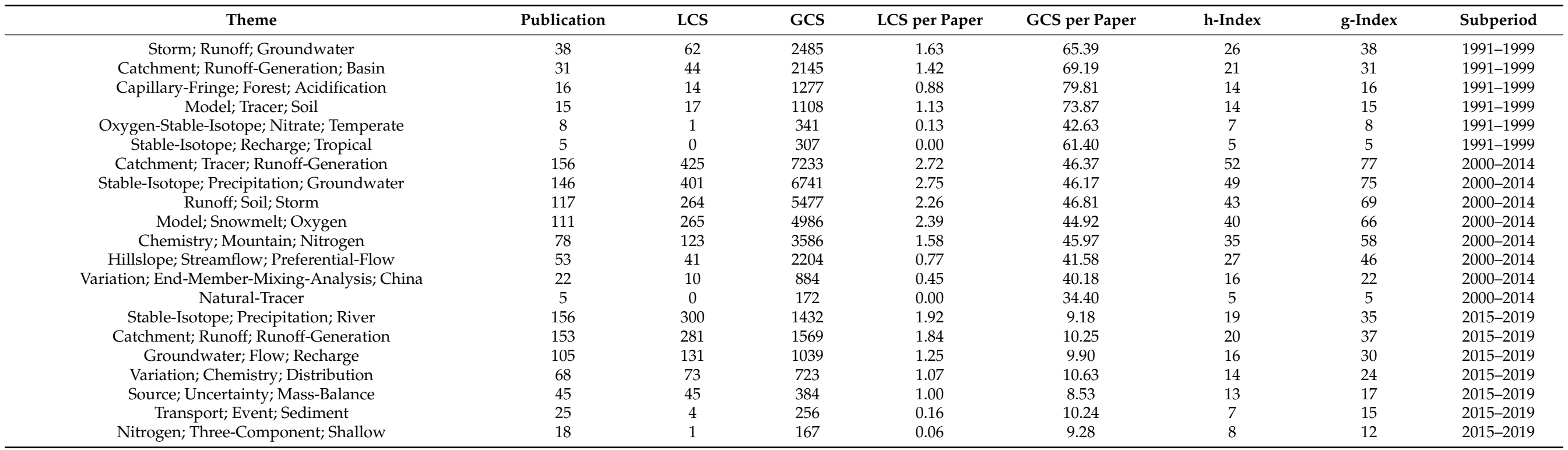


IHS publications in subperiod I were defined by six themes (Figure 4a). 'Capillary fringe', 'forest', and 'acidification' (frequency: 52, Table 5) were the motor themes of IHS, indicating that publications containing these keywords were more important in the research domain. Moreover, 'catchment' that linked with 'runoff-generation' and 'deuterium' showed a motor theme, which showed high centrality and high density and thus represented the processes and mechanisms of streamflow generation at the catchment scale. 'Storm' /'runoff'/'groundwater' (frequency: 132) appeared as a general theme with the highest centrality, the greatest number of publications (38), and the highest LCS (62, Table 6). 'Stable-isotope' /'recharge' /'tropical' (publications: 5; LCS: 0) in quadrant II were isolated themes regarding tropical climates. One specialized theme, 'oxygen-stableisotope' /'nitrate' /'temperate' (publications: 8; LCS: 1), had low density and the lowest centrality. These themes had little influence on IHS research, with few publications and low LCS. However, the final theme for subperiod I linked with 'model' / 'tracer'/'soil' attained certain attention, with 15 articles and 17 LCSs.

In subperiod II (Figure 4b), eight principal topics emerged. The theme 'runoff', 'soil', and 'storm' (frequency: 298, Table 5) developed mainly from 'model' / 'tracer'/'soil' and 'storm' /'runoff' /'groundwater' in subperiod I and shifted to quadrant I as a motor theme with a significant increase in the number of publications (117) and LCS (264) (Table 6). 'Stable-isotope', which was inherited from the previous 'stable-isotope' and 'oxygen-stableisotope', moved to quadrant IV as a basic theme, with the largest centrality and lowest density and was especially linked with 'groundwater' and 'precipitation'. This theme had the second-largest LCS (401), indicating that it was cited widely by other themes. 'Catchment' and 'runoff-generation' had changed to a basic theme in quadrant IV with the largest publication (156) and LCS (425), which came from five themes in subperiod I. A transversal theme in this subperiod includes 'chemistry', 'mountain', and 'nitrogen' (publication: 78; LCS: 123). A new theme named 'hillslope' /'streamflow'/'preferential flow' was located in quadrant III as an emerging theme with a certain number of publications (53) and LCS (41), which consisted of few terms in subperiod I. Some studies focused on 'variation' /'end-member mixing analysis'/'China' (publications: 22) with high density scattered in quadrant II as a marginal and new theme together with 'natural-tracer' (publications: 5). 'Model' shifted to quadrant II with relatively high centrality and approached quadrant I, and its focus changed from 'soil' to 'snowmelt' in IHS. In general, many new contents sprang up in this subperiod.

Subperiod III was characterized by seven clusters, all of which developed from the themes of subperiod II (Figure 4c,d). Three themes, 'stable-isotope' /'precipitation'/'river', 'catchment' /'runoff' /'runoff-generation', and 'groundwater' /'flow' /'recharge', consolidated their roles as basic themes with high centrality and low density. The number of publications and LCS of these themes were much greater than those of other themes in this subperiod (Table 6). More publications (68) focused on 'variation' in regions and/or countries other than China, with increasing centrality compared with subperiod II, and linked to 'chemistry' and 'distribution'. In addition, a new, similar theme was 'source' /'uncertainty' /'mass balance' with publications (45) and LCS (45), which combined the partial information of six themes from subperiod II. 'Transport' /'event'/'sediment' in quadrant II, almost from 'catchment' / 'tracer'/'runoff-generation' in the previous subperiod, appeared as peripheral themes with 25 publications and 4 LCSs. The final theme was 'nitrogen'/'three component' /'shallow' (publications: 18; LCS: 1), which could be considered a marginal theme mainly from the theme 'chemistry'/'mountain'/'nitrogen' in subperiod II.

\section{Discussion}

\subsection{Advances in IHS during Subperiod I}

Although the development of IHS during 1991-1999 was slow, with an average of 3.6 publications per year, there were nine papers in the top 20 most influential documents (Figure 2 and Table 3). These papers focused on issues regarding the processes and meth- 
ods of runoff generation and the role of soil and glacial water on IHS $[6,45,51,57]$. These results indicated that some advances occurred during subperiod I compared with the previous studies before 1986. Our results showed that 'storm' /'runoff' /'groundwater' and 'catchment' /'runoff-generation' / 'basin', whose publication, LCS and LCS per paper were located at the top two positions, represented classified IHS research (Table 6). Moreover, 'catchment' (frequency: 16, Table 5) and 'basin' (6) indicated that IHS research was primarily conducted in small watersheds. This phenomenon was likely induced by two causes: (1) the larger the watershed size was, the larger the isotopic spatial-temporal variation in new and old water likely was. Consequently, these potential changes in events and pre-events in large-scale basins were difficult to characterize quantitatively, which would violate the IHS underlying assumptions 2 and 3; (2) If these variations were to be accounted for, a highly involved watershed sampling strategy should be adopted. However, the funds and labor forces were limited. Therefore, to ensure the accuracy of streamflow separation and save costs, many IHS studies have been implemented in small watersheds where changes in isotopic compositions of runoff sources were as small as possible $[3,4,60]$. Moreover, in this subperiod, a very important literature review was published that systematically summarized the processes and mechanisms of the event and pre-event water transfer to streamflow [6]. Several studies were carried out to test these processes in the forest catchment represented by 'capillary fringe' /'forest' /'acidification' [61,62]. These studies improved the understanding of how the end member water reached a stream in small watersheds. Enhanced recognition, in turn, inspired hydrologists to assess the effect of underlying assumptions on IHS, especially assumptions 2 and 4. McDonnell et al. (1990) [11] developed the incremental mean and incremental intensity mean techniques to capture the changes in the contributions of new water throughout events and considered that incremental weighting was better than the standard mean weighting technique. Therefore, the effect of time isotopic variation in event water on IHS began to be noticed by researchers using the within-storm incremental weighting approach [63,64]. 'Model' combined with 'three components' (1) and 'end-member mixing analysis' (1) suggests that research in subperiod I started to use multivariable methods to separate runoff into three or more components [3,4]. Among these components, 'soil' (6) has attracted more attention [57]. Harris et al. [65] considered that runoff sources came from three reservoirs (direct precipitation on saturated areas, a near-stream saturated zone, and subsurface water in upslope areas), and streamflow was composed of precipitation on saturated areas and soil water exfiltrated from the near-stream saturated zone. Oddly, the themes regarding 'stable-isotope' and 'oxygen-stable-isotope' were the marginal topics, which is likely because several IHS studies combined with 'chemistry' (5), 'water-chemistry' (6), or 'streamwater-chemistry' (6) weakened the role of stable water isotopes in the theme analysis. In addition, the conditions for stable water isotope use were not in all events, and the analysis of samples is expensive [45]. However, streamflow separation in many studies utilized deuterium (6) and oxygen stable isotopes as environmental tracers in this subperiod because of their unquestionably conservative nature $[64,66,67]$. In addition, several studies attempted to explore the contribution of water in ponds or wetlands to runoff, further improving our understanding of the role of surface storage in hydrograph separation [12,67]. In general, the associated IHS hydrological processes were reviewed, and new methods were built in this subperiod to better understand how pre-event and event water reached the stream.

\subsection{Advances in IHS during Subperiod II}

A significant development of IHS occurred in subperiod II. 'Catchment' /'tracer' /'runoffgeneration' was used to characterize the 'flowpath' (frequency: 31, Table 5) of runoff formation and 'residence time' (19) of end-members at catchment scales. These results demonstrated that significant advances occurred in the flow path of end members of different geographic sources to runoff [68]. Moreover, the residence time could provide more information on the age of soil water/groundwater, which helped further differentiate soil water/groundwater from different soil profile layers/aquifers [69]. In 
addition, 'preferential flow' (11) and 'subsurface flow' (11), in the new theme of 'hillslope'/'streamflow' /'preferential flow', focused on the flow path ('macropore') of water movement from the 'unsaturated' hillslope to streamflow [70]. 'Runoff' developed into the motor theme from 'storm' and 'model' in subperiod I (Figure 4b,d). In this theme, the frequency of 'soil' (51) significantly increased relative to subperiod I, indicating that researchers paid more attention to the role of soil water on IHS [71]. Dissolved organic carbon (DOC) measurements were used to distinguish the dominating runoff processes (i.e., lateral subsurface flow), and DOC-rich water was considered from the upper soil horizons [72]. Moreover, 'forest' (37) was likely the main land cover in the theme [73,74]. Generally, these studies regarding the flow path and transit/residence time of streamflow components characterized the hydrological processes of the IHS domain in more detail.

Approximately $84 \%$ of publications in subperiod II were related to 'stable-isotope' / 'groundwater'/'precipitation', indicating that these words were general IHS terms. In addition, the frequency of 'oxygen-stable-isotope' (41) was larger than that of 'deuterium' (29), suggesting that researchers favored the oxygen stable isotope in IHS studies. Overall, compared with subperiod I, stable water isotopes played a more important role in hydrological segmentation in subperiod II. Hydrogen $(\mathrm{H})$ and oxygen $(\mathrm{O})$ are part of the water molecule $\left(\mathrm{H}_{2} \mathrm{O}\right)$, which can directly capture the movements or changes in water $[7,75]$. Consequently, compared with solute traces, stable water isotopes are more ideal tracers for water. Moreover, as the technology upgrades and costs decrease, the percentage of hydrological separation using stable water isotopes increases. However, solute tracers were also important in IHS studies, which could provide extra information to identify the different contributing areas or flow paths in many studies [54,76].

'Variation' and 'end-member mixing analysis' as a novel theme emerged in this subperiod. Approximately $16 \%$ of publications belong to these themes, suggesting that the isotopic variabilities of end members attracted IHS researchers' attention [76]. Several studies found that the temporal and spatial variability in stable water isotopic components occurred widely in event, pre-event, and runoff water [56,77-79]. In addition, there were 111 publications regarding 'model' with 'snowmelt' and 'meltwater', indicating that snow/glacier cover was a classic landscape in IHS research. Therefore, in this subperiod, many studies focused on revealing the spatiotemporal patterns of the meltwater from snowpack, snowmelt, glacier, and frozen soil and their effect on IHS results [80,81]. In addition, evaluating the effect of land use/cover and climate changes on IHS was accompanied by the above themes $[49,82]$.

\subsection{Advances in IHS during Subperiod III}

In subperiod III, the themes of 'stable-isotope'/'precipitation' /'river' (frequency: 760, Table 5) and 'catchment' /'runoff' / 'runoff-generation' (696) developed from subperiod II. These two themes were the foundation of IHS, and there was a great deal of overlapping documents in these themes. Under 'climate change' (29), increasing attention has been directed toward cryosphere meltwater (alpine and cold regions) where glaciers shrink, snowpack melts, and frozen soil degrades $[83,84]$. The glaciers in the Tibetan Plateau are known as Asia's water tower, feeding the largest rivers and sustaining some 2.8 billion people [85]. Therefore, in this subperiod, most IHS documents concentrated on how changes in hydrological processes and runoff sources in the Tibetan Plateau and the surrounding mountains occur with climate warming [86-90]. A majority of these studies were in broad agreement on increasing cryosphere meltwater to runoff or lakes. In addition, 'soil' was grouped with 'catchment', suggesting that soil water became a common topic, and the fourth assumption should be considered in IHS research. 'Groundwater'/'flow' /'recharge' (243) with 'baseflow' (13) was mainly inherited from the themes 'natural-tracer' and 'groundwater' of subperiod II. Except for the traditional IHS topic, which evaluated the contribution and flow path of groundwater to stream, the recharge of groundwater was explored using stable isotope approaches in several studies [91,92]. 
In the 'variation' /'chemistry' / 'distribution' relative to subperiod II, there was increasing interest in 'variation', with 68 publications, suggesting that more research focused on the spatiotemporal heterogeneity of runoff sources $[5,16,17,93,94]$. Moreover, many studies evaluated the 'uncertainty' of end-member contributions to runoff $[87,95]$. This result indicated that there was a strong interest in assessing the uncertainty of end-member contributions to runoff in this subperiod. Several studies have demonstrated that the uncertainty in IHS is mainly induced by the spatiotemporal variability in tracer concentrations $[89,96]$. The temporal isotopic variation is mostly attributed to the amount, intensity, and fractionation of water sources, especially event water [97,98]. Therefore, high-resolution sampling and measurement of events and streamflow water were adopted to characterize these changes in events, which could shed important light on catchment flow pathways, travel times, and short-term hydrological processes [99,100]. Moreover, the long time series of stable isotopes in precipitation, soil/groundwater, and stream water was used to evaluate seasonal and annual hydrological patterns of catchments [101]. The spatial changes were mainly induced by the characteristics of the watershed, such as topography, soil permeability and moisture, local climate, land use/cover change, landscape characteristics, and catchment size $[54,102,103]$. To account for these variations, combined hydrometric, chemical, and isotopic approaches have been utilized to elucidate streamflow generation mechanisms [104]. Moreover, tracer-aided hydrological modeling and remote sensing are becoming increasingly popular tools as they assist with process understanding and source separation $[105,106]$. In general, in subperiod III, quantitative estimates of the variations in different water sources and their flow paths became common issues in IHS studies using multiple technologies, further addressing the underlying assumptions two and three. In addition, two themes, 'nitrogen' /'three component'/'shallow' and 'transport' /'event'/'sediment', were also developed from the themes in subperiod II but had little influence on the field of IHS.

\subsection{Future Research Trends}

Based on the results of thematic analysis, there are several trends in IHS research for the future. The themes of 'catchment', 'runoff-generation', 'groundwater', and 'precipitation' are the core IHS issues with the greatest number of publications and largest LCS throughout the entire period. These themes will still be located in the center of IHS research in the coming years. Although there was a significant increase in the interest in how to address the effect of spatial and temporal isotopic heterogeneity of precipitation on IHS, similar studies regarding the isotopic spatial heterogeneity of groundwater remain limited $[16,17,107,108]$. Therefore, how the isotopic spatial and temporal changes in groundwater affect IHS will be one of the important trends. Scholars focused on soil water in subperiod II, making it a basic IHS theme in subperiod III. Studies on the contribution of soil water to runoff have been implemented mostly in humid regions, and most of these studies considered that soil water was the main source of runoff $[70,103,109,110]$. However, knowledge of the contribution of soil water to streamflow remains limited in arid and semi-arid areas [10]. More work is needed regarding the contribution of soil water to streamflow in these regions [111]. In addition, how to decrease the uncertainty of end-member contributions to streamflow is one of the important issues in the future trends in IHS research $[87,112]$.

Many studies have applied a combined approach, including hydrometeorological measurements, water chemistry, and stable isotopes, to improve the understanding of hydrological processes in the IHS domain [113]. However, at the same time, there were significant increasing costs and labor when using the synthetic method in IHS studies, which would keep catchment hydrologists and administrators who had limited funds from understanding the behavior of hydrologic systems. Several studies have sought new, feasible methods for IHS. Xing et al. [114] introduced the path analysis method to separate the streamflow, which allowed multicomponent hydrograph separation using one tracer and could provide results similar to those of the end-member mixing approach. Kirchner [115] developed an ensemble approach to hydrograph separation, which was 
insensitive to the variations in end-member signatures and isotopic fractionation. These new methods should be applied for hydrograph separation in the heterogeneous remote regions or mountains, which could enable a wide range of future analyses of catchment hydrology [116].

\section{Conclusions}

IHS is a novel research field that has shown a great shift in separating runoff into pre-event and event water throughout its production lifetime. Although IHS has developed over several decades, many questions and challenges remain in the generation of runoff. This study used text mining and bibliometric analysis to present a quantitative and systematic review of IHS documents published from 1986 to 2019, thus tracing the evolution of the field. The number of IHS documents has increased rapidly in recent years, but the total sum of documents remains relatively small. The most influential documents in the field were published in subperiod I and subperiod II. Significant improvements can still be made. The topic analysis indicated that the contributions and mechanisms of precipitation, groundwater, and soil water to runoff were the core and base topics in the IHS field. Most IHS studies were carried out in watersheds covered with forest, glaciers, and snow. How to clearly characterize the process of runoff generation, the effects of spatial-temporal heterogeneity of precipitation and groundwater, the assessment of the uncertainty of the IHS result, the contribution of soil water in arid and semi-arid areas, and the verification and application of the new IHS methods are future trends in IHS research.

The study had some limitations caused by the method. First, documents published before 1986 were not included in our dataset. Second, it is possible that some IHS documents are not included in the WoS core database or that we did not retrieve some papers. A possible solution to overcome these limitations is the use of more sources and the retrieval of a larger number of IHS search terms. In general, however, this study has provided novel insights into the research characteristics and evolution of topics in the field of IHS. Moreover, the methods described in this study have great value for all research fields and thus have broad applicability.

Supplementary Materials: The following are available online at https://www.mdpi.com/article/ 10.3390/w13182529/s1, Data: data.xlsx.

Author Contributions: Conceptualization, Y.Y. and J.Q.; methodology, Y.Y.; formal analysis, Y.Y.; data curation, Y.Y.; writing — original draft preparation, Y.Y.; writing—review and editing, Z.J.; visualization, Y.Y.; supervision, J.Q. and Z.J.; funding acquisition, Y.Y., J.Q., and Z.J. All authors have read and agreed to the published version of the manuscript.

Funding: This research was funded by the Strategic Priority Research Program of the Chinese Academy of Sciences (XDB40020300), the National Natural Science Foundation of China (41790444), the National Key R\&D Program of China (2018YFC1504701), and the open-end funds of the State Key Laboratory of Loess and Quaternary Geology (SKLLQG2026), and the National Social Science Foundation of China (No.19ZDA348) and the Humanities and Social Science Foundation, Ministry of Education of the People's Republic of China (No.19YJC880138).

Institutional Review Board Statement: Not applicable.

Informed Consent Statement: Not applicable.

Data Availability Statement: The data that support the findings of this study are available in the Supplementary Material of this article.

Conflicts of Interest: The authors declare no conflict of interest.

\section{References}

1. Hubert, P.; Marin, E.; Meybeck, M.; Oliver, P.; Siwertz, E. Aspects Hydrologique, Gèochimique et Sèdimentologique de la Crue Exceptionnelle de la Dranse du Chablais du 22 Septembre 1968. Arch. Sci. (Genève) 1968, 3, 581-604.

2. Munoz-Villers, L.E.; McDonnell, J.J. Runoff generation in a steep, tropical montane cloud forest catchment on permeable volcanic substrate. Water Resour. Res. 2012, 48, WR011316. [CrossRef] 
3. Brown, V.A.; McDonnell, J.J.; Burns, D.A.; Kendall, C. The role of event water, a rapid shallow flow component, and catchment size in summer stormflow. J. Hydrol. 1999, 217, 171-190. [CrossRef]

4. McDonnell, J.J.; Stewart, M.K.; Owens, I.F. Effect of catchment-scale subsurface mixing on stream isotopic response. Water Resour. Res. 1991, 27, 3065-3073. [CrossRef]

5. Schmieder, J.; Hanzer, F.; Marke, T.; Garvelmann, J.; Warscher, M.; Kunstmann, H.; Strasser, U. The importance of snowmelt spatiotemporal variability for isotope-based hydrograph separation in a high-elevation catchment. Hydrol. Earth Syst. Sci. 2016, 20, 5015-5033. [CrossRef]

6. Buttle, J.M. Isotope hydrograph separations and rapid delivery of pre-event water from drainage basins. Prog. Phys. Geogr. 1994, 18, 16-41. [CrossRef]

7. Klaus, J.; McDonnell, J.J. Hydrograph separation using stable isotopes: Review and evaluation. J. Hydrol. 2013, 505, 47-64. [CrossRef]

8. Kong, Y.L.; Pang, Z.H. Isotope hydrograph separation in alpine catchments: A review. Sci. Cold Arid Reg. 2011, 1, 86-91. (In Chinese)

9. Tetzlaff, D.; Buttle, J.; Carey, S.K.; McGuire, K.; Laudon, H.; Soulsby, C. Tracer-based assessment of flow paths, storage and runoff generation in northern catchments: A review. Hydrol. Process. 2015, 29, 3475-3490. [CrossRef]

10. Burns, D.A. Stormflow-hydrograph separation based on isotopes: The thrill is gone-What's next? Hydrol. Process. 2002, 16, 1515-1517. [CrossRef]

11. McDonnell, J.J.; Bonell, M.; Stewart, M.K.; Pearce, A.J. Deuterium variations in storm rainfall-Implications for stream hydrograph separation. Water Resour. Res. 1990, 26, 455-458. [CrossRef]

12. Burns, D.A.; McDonnell, J.J. Effects of a beaver pond on runoff processes: Comparison of two headwater catchments. J. Hydrol. 1998, 205, 248-264. [CrossRef]

13. Taylor, S.; Feng, X.H.; Kirchner, J.W.; Osterhuber, R.; Klaue, B.; Renshaw, C.E. Isotopic evolution of a seasonal snowpack and its melt. Water Resour. Res. 2001, 37, 759-769. [CrossRef]

14. Huth, A.K.; Leydecker, A.; Sickman, J.O.; Bales, R.C. A two-component hydrograph separation for three high-elevation catchments in the Sierra Nevada, California. Hydrol. Process. 2004, 18, 1721-1733. [CrossRef]

15. Jefferson, A.J.; Bell, C.D.; Clinton, S.M.; McMillan, S.K. Application of isotope hydrograph separation to understand contributions of stormwater control measures to urban headwater streams. Hydrol. Process. 2015, 29, 5290-5306. [CrossRef]

16. Fischer, B.M.C.; van Meerveld, H.J.; Seibert, J. Spatial variability in the isotopic composition of rainfall in a small headwater catchment and its effect on hydrograph separation. J. Hydrol. 2017, 547, 755-769. [CrossRef]

17. Cayuela, C.; Latron, J.; Geris, J.; Llorens, P. Spatio-temporal variability of the isotopic input signal in a partly forested catchment: Implications for hydrograph separation. Hydrol. Process. 2019, 33, 36-46. [CrossRef]

18. Zhang, Y.; Chen, M.; Liu, L. A review on text mining. In Proceedings of the 2015 6th IEEE International Conference on Software Engineering and Service Science, Beijing, China, 23-25 September 2015.

19. Zhu, J.-J.; Dressel, W.; Pacion, K.; Ren, Z.J. ES\&T in the 21st Century: A Data-Driven Analysis of Research Topics, Interconnections, And Trends in the Past 20 Years. Environ. Sci. Technol. 2021, 55, 3453-3464.

20. Sun, Y.W.; Zhai, Y. Mapping the knowledge domain and the theme evolution of appropriability research between 1986 and 2016 : A scientometric review. Scientometrics 2018, 116, 203-230. [CrossRef]

21. Choi, J.; Yi, S.; Lee, K.C. Analysis of keyword networks in MIS research and implications for predicting knowledge evolution. Inf. Manag. 2011, 48, 371-381. [CrossRef]

22. Li, J.; Wang, M.; Ho, Y. Trends in research on global climate change: A Science Citation Index Expanded-based analysis. Glob. Planet. Chang. 2011, 77, 13-20. [CrossRef]

23. Yao, X.; Zhang, Y.; Zhang, L.; Zhou, Y. A bibliometric review of nitrogen research in eutrophic lakes and reservoirs. J. Environ. Sci. 2018, 66, 274-285. [CrossRef]

24. Chen, X.; Chen, J.; Wu, D.; Xie, Y.; Li, J. Mapping the research trends by co-word analysis based on keywords from funded project. Procedia Comput. Sci. 2016, 91, 547-555. [CrossRef]

25. Ellegaard, O. The application of bibliometric analysis: Disciplinary and user aspects. Scientometrics 2018, 116, 181-202. [CrossRef]

26. Li, W.; Dong, H.; Yu, H.; Wang, D.; Yu, H. Global characteristics and trends of research on ceramic membranes from 1998 to 2016: Based on bibliometric analysis combined with information visualization analysis. Ceram. Int. 2018, 44, 6926-6934. [CrossRef]

27. Cuccurullo, C.; Aria, M.; Sarto, F. Foundations and trends in performance management. A twenty-five years bibliometric analysis in business and public administration domains. Scientometrics 2016, 108, 595-611. [CrossRef]

28. Merigo, J.M.; Pedrycz, W.; Weber, R.; de la Sotta, C. Fifty years of Information Sciences: A bibliometric overview. Inf. Sci. 2018, 432, 245-268. [CrossRef]

29. Padilla, F.M.; Gallardo, M.; Manzano-Agugliaro, F. Global trends in nitrate leaching research in the 1960-2017 period. Sci. Total Environ. 2018, 643, 400-413. [CrossRef] [PubMed]

30. Todeschini, R.; Baccini, A. Handbook of Bibliometric Indicators: Quantitative Tools for Studying and Evaluating Research; Wiley-VCH: Weinheim, Germany, 2016.

31. Chen, H.; Jiang, W.; Yang, Y.; Yang, Y.; Man, X. State of the art on food waste research: A bibliometrics study from 1997 to 2014. J. Clean. Prod. 2017, 140, 840-846. [CrossRef] 
32. Muhuri, P.K.; Shukla, A.K.; Abraham, A. Industry 4.0: A bibliometric analysis and detailed overview. Eng. Appl. Artif. Intell. 2019, 78, 218-235. [CrossRef]

33. Gao, W.; Guo, H.C. Nitrogen research at watershed scale: A bibliometric analysis during 1959-2011. Scientometrics 2014, 99, 737-753. [CrossRef]

34. Aria, M.; Misuraca, M.; Spano, M. Mapping the Evolution of Social Research and Data Science on 30 Years of Social Indicators Research. Soc. Indic. Res. 2020, 149, 803-831. [CrossRef]

35. Small, H. Visualizing science by citation mapping. J. Am. Soc. Inf. Sci. 1999, 50, 799-813. [CrossRef]

36. Weismayer, C.; Pezenka, I. Identifying emerging research fields: A longitudinal latent semantic keyword analysis. Scientometrics 2017, 113, 1757-1785. [CrossRef]

37. Ho, Y.; Satoh, H.; Lin, S. Japanese lung cancer research trends and performance in Science Citation Index. Intern. Med. 2010, 49, 2219-2228. [CrossRef]

38. Cobo, M.J.; López-Herrera, A.G.; Herrera-Viedma, E.; Herrera, F. An approach for detecting, quantifying, and visualizing the evolution of a research field: A practical application to the fuzzy sets theory field. J. Informetr. 2011, 5, 146-166. [CrossRef]

39. Seabra, D.; Caldeira-pires, A. The thermodynamic rarity concept: A systematic review. Ecol. Indic. 2020, 108, 105689. [CrossRef]

40. Hirsch, J.E. An index to quantify an individual's scientific research output. Proc. Natl. Acad. Sci. USA 2005, 46, 16569-16572. [CrossRef]

41. Egghe, L. Theory and practise of the g-index. Scientometries 2006, 69, 131-152. [CrossRef]

42. Callon, M.; Courtial, J.P.; Laville, F. Co-word analysis as a tool for describing the network of interactions between basic and technological research: The case of polymer chemsitry. Scientometrics 1991, 22, 155-205. [CrossRef]

43. Coulter, N.; Monarch, I.; Konda, S. Software engineering as seen through its research literature: A study in co-word analysis. J. Am. Soc. Inf. Sci. 1998, 49, 1206-1223. [CrossRef]

44. Aria, M.; Cuccurullo, C. bibliometrix: An R-tool for comprehensive science mapping analysis. J. Informetr. 2017, 11, 959-975. [CrossRef]

45. Hooper, R.P.; Shoemaker, C.A. A comparison of chemical and isotopic hydrograph separation. Water Resour. Res. 1986, 22, 1444-1454. [CrossRef]

46. Wels, C.; Cornett, R.J.; Lazerte, B.D. Hydrograph separatio - A comparison of geochemical and isotopic tracers. J. Hydrol. 1991, 122, 253-274. [CrossRef]

47. Laudon, H.; Hemond, H.F.; Krouse, R.; Bishop, K.H. Oxygen 18 fractionation during snowmelt: Implications for spring flood hydrograph separation. Water Resour. Res. 2002, 38, WR001510. [CrossRef]

48. Ogunkoya, O.O. Analysis of storm hydrograph and flow pathways using a 3-component hydrograph separation model. J. Hydrol. 1993; 142, 71-88.

49. Kong, Y.L.; Pang, Z.H. Evaluating the sensitivity of glacier rivers to climate change based on hydrograph separation of discharge. J. Hydrol. 2012, 434, 121-129. [CrossRef]

50. Hinton, M.J.; Schiff, S.L.; English, M.C. Examining the contributions of glacial till water to storm runoff using 2-component and 3-component hydrograph separations. Water Resour. Res. 1994, 30, 983-993. [CrossRef]

51. Laudon, H.; Slaymaker, O. Hydrograph separation using stable isotopes, silica and electrical conductivity: An alpine example. J. Hydrol. 1997, 201, 82-101. [CrossRef]

52. Ladouche, B.; Probst, A.; Viville, D.; Idir, S.; Baque, D.; Loubet, M.; Probst, J.L.; Bariac, T. Hydrograph separation using isotopic, chemical and hydrological approaches (Strengbach catchment, France). J. Hydrol. 2001, 242, 255-274. [CrossRef]

53. Taylor, S.; Feng, X.H.; Williams, M.; McNamara, J. How isotopic fractionation of snowmelt affects hydrograph separation. Hydrol. Process. 2002, 16, 3683-3690. [CrossRef]

54. Shanley, J.B.; Kendall, C.; Smith, T.E.; Wolock, D.M.; McDonnell, J.J. Controls on old and new water contributions to stream flow at some nested catchments in Vermont, USA. Hydrol. Process. 2002, 16, 589-609. [CrossRef]

55. Lyon, S.W.; Desilets, S.L.E.; Troch, P.A. A tale of two isotopes: Differences in hydrograph sepatation for a runoff event when using delta D versus delta O-18. Hydrol. Process. 2009, 23, 2095-2101. [CrossRef]

56. Liu, Y.H.; Fan, N.J.; An, S.Q.; Bai, X.H.; Liu, F.D.; Xu, Z.; Wang, Z.S.; Liu, S.R. Characteristics of water isotopes and hydrograph separation during the wet season in the Heishui River, China. J. Hydrol. 2008, 353, 314-321. [CrossRef]

57. Bazemore, D.E.; Eshleman, K.N.; Hollenbeck, K.J. The role of soil-water in stormflow generation in a forested headwater catchment-Synthesis of natural tracer and hydrometric evidence. J. Hydrol. 1994, 162, 47-75. [CrossRef]

58. Unnikrishna, P.V.; McDonnell, J.J.; Kendall, C. Isotope variations in a Sierra Nevada snowpack and their relation to meltwater. J. Hydrol. 2002, 260, 38-57. [CrossRef]

59. Weiler, M.; McGlynn, B.L.; McGuire, K.J.; McDonnell, J.J. How does rainfall become runoff? A combined tracer and runoff transfer function approach. Water Resour. Res. 2003, 39, 1315. [CrossRef]

60. Maclean, R.A.; English, M.C.; Schiff, S.L. Hydrological and hydrochemical response of a small canadian shield catchment to late winter rain-on-snow events. Hydrol. Process. 2010, 9, 845-863. [CrossRef]

61. Buttle, J.M.; Sami, K. Testing the groundwater ridging hypothesis of streamflow generation during snowmelt in a forested catchment. J. Hydrol. 1992, 135, 53-72. [CrossRef]

62. Peters, D.L.; Buttle, J.M.; Taylor, C.H.; Lazerte, B.D. Runoff production in a forested, shallow soil, Canadian shield basin. Water Resour. Res. 1995, 31, 1291-1304. [CrossRef] 
63. Weiler, M.; Scherrer, S.; Naef, F.; Burlando, P. Hydrograph separation of runoff components based on measuring hydraulic state variables, tracer experiments, and weighting methods. In Integrated Methods in Catchment Hydrology: Tracer, Remote Sensing and New Hydrometric Techniques; Leibundgut, C., McDonnell, J., Schultz, G., Eds.; IAHS Press: Wallingford, UK, 1999 ; pp. $249-255$.

64. Buttle, J.M.; Vonk, A.M.; Taylor, C.H. Applicability of isotopic hydrograph separation in a suburban basin during snowmelt. Hydrol. Process. 1995, 9, 197-211. [CrossRef]

65. Harris, D.M.; McDonnell, J.J.; Rodhe, A. Hydrograph separation using continuous open system isotpe mixing. Water Resour. Res. 1995, 31, 157-171. [CrossRef]

66. Lqbal, M.Z. Application of environmental isotopes in storm-discharge analysis of two contrasting stream channels in a watershed. Water Res. 1998, 32, 2959-2968.

67. Mccartney, M.P.; Neal, C.; Neal, M. Use of deuterium to understand runoff generation in a headwater catchment containing a dambo. Hydrol. Earth Syst. Sci. 1998, 2, 65-76. [CrossRef]

68. Orlowski, N.; Lauer, F.; Kraft, P.; Frede, H.; Breuer, L. Linking spatial patterns of groundwater table dynamics and streamflow generation processes in a small developed catchment. Water 2014, 6, 3085-3117. [CrossRef]

69. Soulsby, C.; Malcolm, R.; Helliwell, R.; Ferrier, R.C.; Jenkins, A. Isotope hydrology of the Allt a' Mharcaidh catchment, Cairngorms, Scotland: Implications for hydrological pathways and residence times. Hydrol. Process. 2000, 14, 747-762. [CrossRef]

70. Zhao, P.; Tang, X.; Zhao, P.; Wang, C.; Tang, J. Tracing water flow from sloping farmland to streams using oxygen-18 isotope to study a small agricultural catchment in southwest China. Soil Tillage Res. 2013, 134, 180-194. [CrossRef]

71. Dahlke, H.E.; Easton, Z.M.; Lyon, S.W.; Todd Walter, M.; Destouni, G.; Steenhuis, T.S. Dissecting the variable source area concept-Subsurface flow pathways and water mixing processes in a hillslope. J. Hydrol. 2012, 420-421, 125-141. [CrossRef]

72. Casper, M.C.; Volkmann, H.N.; Waldenmeyer, G.; Plate, E.J. The separation of flow pathways in a sandstone catchment of the Northern Black Forest using DOC and a nested Approach. Phys. Chem. Earth 2003, 28, 269-275. [CrossRef]

73. Marc, V.; Didon-Lescot, J.F.; Michael, C. Investigation of the hydrological processes using chemical and isotopic tracers in a small Mediterranean forested catchment during autumn recharge. J. Hydrol. 2001, 247, 215-229. [CrossRef]

74. Goller, R.; Wilcke, W.; Leng, M.J.; Tobschall, H.J.; Wagner, K.; Valarezo, C.; Zech, W. Tracing water paths through small catchments under a tropical montane rain forest in south Ecuador by an oxygen isotope approach. J. Hydrol. 2005, 308, 67-80. [CrossRef]

75. Kendall, C.; Mcdonnell, J. Isotope Tracers in Catchment Hydrology; Elsevier: Oxford, UK, 1998.

76. Barthold, F.K.; Wu, J.; Vache, K.B.; Schneider, K.; Frede, H.-G.; Breuer, L. Identification of geographic runoff sources in a data sparse region: Hydrological processes and the limitations of tracer-based approaches. Hydrol. Process. 2010, 24, $2313-2327$. [CrossRef]

77. Koeniger, P.; Hubbart, J.A.; Link, T.; Marshall, J.D. Isotopic variation of snow cover and streamflow in response to changes in canopy structure in a snow-dominated mountain catchment. Hydrol. Process. 2008, 22, 557-566. [CrossRef]

78. Koeniger, P.; Leibundgut, C.; Stichler, W. Spatial and temporal characterisation of stable isotopes in river water as indicators of groundwater contribution and confirmation of modelling results; a study of the Weser river, Germany. Isot. Environ. Health Stud. 2009, 45, 289-302. [CrossRef] [PubMed]

79. Jin, L.; Siegel, D.I.; Lautz, L.K.; Lu, Z. Identifying streamflow sources during spring snowmelt using water chemistry and isotopic composition in semi-arid mountain streams. J. Hydrol. 2012, 470, 289-301. [CrossRef]

80. Maurya, A.S.; Shah, M.; Deshpande, R.D.; Bhardwaj, R.M.; Prasad, A.; Gupta, S.K. Hydrograph separation and precipitation source identification using stable water isotopes and conductivity: River Ganga at Himalayan foothills. Hydrol. Process. 2011, 25, 1521-1530. [CrossRef]

81. Taylor, S.; Feng, X.H.; Renshaw, C.E.; Kirchner, J.W. Isotopic evolution of snowmelt 2. Verification and parameterization of a one-dimensional model using laboratory experiments. Water Resour. Res. 2002, 38, WR000815. [CrossRef]

82. Gremillion, P.; Gonyeau, A.; Wanielista, M. Application of alternative hydrograph separation models to detect changes in flow paths in a watershed undergoing urban development. Hydrol. Process. 2000, 14, 1485-1501. [CrossRef]

83. Engel, M.; Penna, D.; Bertoldi, G.; Dell'Agnese, A.; Soulsby, C.; Comiti, F. Identifying run-off contributions during melt-induced run-off events in a glacierized alpine catchment. Hydrol. Process. 2016, 30, 343-364. [CrossRef]

84. Yang, Y.; Wu, Q.; Jin, H. Evolutions of water stable isotopes and the contributions of cryosphere to the alpine river on the Tibetan Plateau. Environ. Earth Sci. 2016, 75, 49. [CrossRef]

85. Gui, J.; Li, Z.; Yuan, R.; Xue, J. Hydrograph separation and the influence from climate warming on runoff in the north-eastern Tibetan Plateau. Quat. Int. 2019, 525, 45-53. [CrossRef]

86. Li, Z.; Feng, Q.; Liu, W.; Wang, T.; Guo, X.; Li, Z.; Gao, Y.; Pan, Y.; Guo, R.; Jia, B.; et al. The stable isotope evolution in Shiyi glacier system during the ablation period in the north of Tibetan Plateau, China. Quat. Int. 2015, 380, 262-271.

87. Pu, T.; Qin, D.; Kang, S.; Niu, H.; He, Y.; Wang, S. Water isotopes and hydrograph separation in different glacial catchments in the southeast margin of the Tibetan Plateau. Hydrol. Process. 2017, 31, 3810-3826. [CrossRef]

88. Li, Z.; Gui, J.; Wang, X.; Feng, Q.; Zhao, T.; Ouyang, C.; Guo, X.; Zhang, B.; Shi, Y. Water resources in inland regions of central Asia: Evidence from stable isotope tracing. J. Hydrol. 2019, 570, 1-16. [CrossRef]

89. Wu, J.-K.; Wu, X.-P.; Hou, D.-J.; Liu, S.-W.; Zhang, X.-Y.; Qin, X. Streamwater hydrograph separation in an alpine glacier area in the Qilian Mountains, northwestern China. Hydrol. Sci. J. 2016, 61, 2399-2410.

90. Williams, M.W.; Wilson, A.; Tshering, D.; Thapa, P.; Kayastha, R.B. Using geochemical and isotopic chemistry to evaluate glacier melt contributions to the Chamkar Chhu (river), Bhutan. Ann. Glaciol. 2016, 57, 339-348. [CrossRef] 
91. Padilla, C.; Onda, Y.; Iida, T. Interaction between runoff-Bedrock groundwater in a steep headwater catchment underlain by sedimentary bedrock fractured by gravitational deformation. Hydrol. Process. 2015, 29, 4398-4412. [CrossRef]

92. Keesari, T.; Sharma, D.A.; Rishi, M.S.; Pant, D.; Mohokar, H.V.; Jaryal, A.K.; Sinha, U.K. Isotope investigation on groundwater recharge and dynamics in shallow and deep alluvial aquifers of southwest Punjab. Appl. Radiat. Isot. 2017, 129, 163-170. [CrossRef]

93. Sun, C.; Chen, Y.; Li, X.; Li, W. Analysis on the streamflow components of the typical inland river, Northwest China. Hydrol. Sci. J. 2016, 61, 970-981. [CrossRef]

94. Ruecker, A.; Boss, S.; Kirchner, J.W.; von Freyberg, J. Monitoring snowpack outflow volumes and their isotopic composition to better understand streamflow generation during rain-on-snow events. Hydrol. Earth Syst. Sci. 2019, 23, 2983-3005. [CrossRef]

95. Markovich, K.H.; Dahlke, H.E.; Luis Arumi, J.; Maxwell, R.M.; Fogg, G.E. Bayesian hydrograph separation in a minimally gauged alpine volcanic watershed in central Chile. J. Hydrol. 2019, 575, 1288-1300. [CrossRef]

96. Pu, T.; He, Y.Q.; Zhu, G.F.; Zhang, N.N.; Du, J.K.; Wang, C.F. Characteristics of water stable isotopes and hydrograph separation in Baishui catchment during the wet season in Mt.Yulong region, south western China. Hydrol. Process. 2013, 27, 3641-3648. [CrossRef]

97. Qu, S.; Wang, Y.; Zhou, M.; Liu, H.; Shi, P.; Yu, Z.; Xiang, L. Temporal O-18 and deuterium variations in hydrologic components of a small watershed during a typhoon event. Isot. Environ. Health Stud. 2017, 53, 172-183. [CrossRef]

98. Rucker, A.; Zappa, M.; Boss, S.; von Freyberg, J. An optimized snowmelt lysimeter system for monitoring melt rates and collecting samples for stable water isotope analysis. J. Hydrol. Hydromech. 2019, 67, 20-31. [CrossRef]

99. Kim, H.; Cho, S.H.; Lee, D.; Jung, Y.Y.; Kim, Y.H.; Koh, D.C.; Lee, J. Influence of pre-event water on streamflow in a granitic watershed using hydrograph separation. Environ. Earth Sci. 2017, 76, 76-82. [CrossRef]

100. Mosquera, G.M.; Segura, C.; Crespo, P. Flow partitioning modelling using high-resolution isotopic and electrical conductivity Data. Water 2018, 10, 904. [CrossRef]

101. Peralta-Tapia, A.; Sponseller, R.A.; Tetzlaff, D.; Soulsby, C.; Laudon, H. Connecting precipitation inputs and soil flow pathways to stream water in contrasting boreal catchments. Hydrol. Process. 2015, 29, 3546-3555. [CrossRef]

102. Qu, S.-M.; Shan, S.; Chen, X.; Zhou, M.-M.; Liu, H. Isotopic analysis of water cycle elements in different land covers in a small headwater watershed. Water Policy 2017, 19, 574-585. [CrossRef]

103. Munoz-Villers, L.E.; McDonnell, J.J. Land use change effects on runoff generation in a humid tropical montane cloud forest region. Hydrol. Earth Syst. Sci. 2013, 17, 3543-3560. [CrossRef]

104. Shanley, J.B.; Sebestyen, S.D.; McDonnell, J.J.; McGlynn, B.L.; Dunne, T. Water's Way at Sleepers River watershed-Revisiting flow generation in a post-glacial landscape, Vermont USA. Hydrol. Process. 2015, 29, 3447-3459. [CrossRef]

105. Zhang, W.; Kang, S.-C.; Shen, Y.-P.; He, J.-Q.; Chen, A.-A. Response of snow hydrological processes to a changing climate during 1961 to 2016 in the headwater of Irtysh River Basin, Chinese Altai Mountains. J. Mt. Sci. 2017, 14, 2295-2310. [CrossRef]

106. Tunaley, C.; Tetzlaff, D.; Birkel, C.; Soulsby, C. Using high-resolution isotope data and alternative calibration strategies for a tracer-aided runoff model in a nested catchment. Hydrol. Process. 2017, 31, 3962-3978. [CrossRef]

107. Sahraei, A.; Kraft, P.; Windhorst, D.; Breuer, L. High-resolution, in situ monitoring of stable isotopes of water revealed insight into hydrological response behavior. Water 2020, 12, 565. [CrossRef]

108. Penna, D.; van Meerveld, H.J. Spatial variability in the isotopic composition of water in small catchments and its effect on hydrograph separation. Wiley Interdiscip. Rev.-Water 2019, 6, e1367. [CrossRef]

109. Li, Z.; Feng, Q.; Wang, Q.J.; Yong, S.; Cheng, A.; Li, J. Contribution from frozen soil meltwater to runoff in an in-land river basin under water scarcity by isotopic tracing in northwestern China. Glob. Planet. Chang. 2016, 136, 41-51.

110. Penna, D.; van Meerveld, H.J.; Oliviero, O.; Zuecco, G.; Assendelft, R.S.; Dalla Fontana, G.; Borga, M. Seasonal changes in runoff generation in a small forested mountain catchment. Hydrol. Process. 2015, 29, 2027-2042. [CrossRef]

111. Suarez, V.V.C.; Okello, A.; Wenninger, J.W.; Uhlenbrook, S. Understanding runoff processes in a semi-arid environment through isotope and hydrochemical hydrograph separations. Hydrol. Earth Syst. Sci. 2015, 19, 4183-4199. [CrossRef]

112. Yang, W.; Xiao, C.; Liang, X. Technical note: Analytical sensitivity analysis and uncertainty estimation of baseflow index calculated by a two-component hydrograph separation method with conductivity as a tracer. Hydrol. Earth Syst. Sci. 2019, 23, 1103-1112. [CrossRef]

113. Tardy, Y.; Bustillo, V.; Roquin, C.; Mortatti, J.; Victoria, R. The Amazon. Bio-geochemistry applied to river basin management Part I. Hydro-climatology, hydrograph separation, mass transfer balances, stable isotopes, and modelling. Appl. Geochem. 2005, 20, 1746-1829. [CrossRef]

114. Xing, B.; Liu, Z.; Liu, G.; Zhang, J. Determination of runoff components using path analysis and isotopic measurements in a glacier-covered alpine catchment (upper Hailuogou Valley) in southwest China. Hydrol. Process. 2015, 29, 3065-3073. [CrossRef]

115. Kirchner, J.W. Quantifying new water fractions and transit time distributions using ensemble hydrograph separation: Theory and benchmark tests. Hydrol. Earth Syst. Sci. 2019, 23, 303-349. [CrossRef]

116. Knapp, J.L.A.; Neal, C.; Schlumpf, A.; Neal, M.; Kirchner, J.W. New water fractions and transit time distributions at Plynlimon, Wales, estimated from stable water isotopes in precipitation and streamflow. Hydrol. Earth Syst. Sci. 2019, 23, 4367-4388. [CrossRef] 